\title{
Framework for incorporating stakeholders' preferences in lifecycle welding flux design
}

\author{
Ademola David Adeyeye 1,* and Damola Emmanuel Osinubi 2 \\ Department of Industrial and Production Engineering, University of Ibadan, Ibadan, Nigeria.
}

Global Journal of Engineering and Technology Advances, 2021, 07(02), 012-025

Publication history: Received on 18 March 2021; revised on 30 April 2021; accepted on 03 May 2021

Article DOI: https://doi.org/10.30574/gjeta.2021.7.2.0064

\begin{abstract}
Welding flux design involves optimising multiple quality attributes which are often conflicting and are of varying degree of concern to the stakeholders. The attributes are often selected as design criteria and are sometimes at different levels in the hierarchy such as primary, secondary and tertiary attributes. The articulation and incorporation of the opinions of stakeholders concerning the intensity of importance attached to each attribute at all the levels in the hierarchy in the optimisation process has remained a challenge. In this study, a framework was proposed for the articulation and incorporation of the preferences of stakeholders concerning all levels of attributes and illustrated with a lifecycle welding flux design case from the literature involving 5, 21 and 25 primary, secondary and tertiary criteria, respectively. Fifteen out of the 21 secondary criteria could not be further unbundled and were added to the tertiary criteria to make 40 lowest level criteria. The subjective judgements of stakeholders were converted to weighting coefficients using the analytical hierarchy process. The coefficients for the lowest level criteria were converted to global weights $\left(w_{c}^{G}\right)$ which were the preference indices for use in the optimisation models. Based on the values of $w_{c}^{G}$, moisture pick-up, extrudability and slag detachability were ranked $1^{\text {st }}, 2^{\text {nd }}$, and $3^{\text {rd }}$ respectively and the respective 38 th, 39 th and 40 th lowest level criteria were fume generation, dilution and charpy impart strength.
\end{abstract}

Keywords: Relative importance; Multiple response optimization; Design objectives; Sub-criteria; Welding flux quality optimization; Analytical hierarchy process

\section{Introduction}

Welding flux design like many engineering design problems involves taking many quality requirements into account simultaneously. These requirements often cover the entire life cycle of the artefact and as a result the concerns of many stakeholders are considered. For instance, the manufacturability of the flux is of concern to the manufacturer of the flux while the concern of the welder, are those quality issues relating to the operational characteristics such as arc stability, slag detachability, penetration and spatter. The ability of the weldment produced with the flux to meet service requirements and withstand the hostile service environment is of utmost concern to the user of the welded product. The by-products of welding such as fumes and slag which pollute air, water and soil are of health and environmental concerns. The welding Flux Designer (WFD) has to identify all the requirements that are of concern to the Welding Flux Stakeholders (WFS). These quality requirements eventually become the design objectives or criteria. How to obtain the flux that best meet all the multiple and often conflicting criteria has been a challenge. Prior to the last one-decade, the methods of obtaining optimal welding flux had been by lengthy and expensive experiments and the flux so developed could not be guaranteed to be optimum because of the random nature of the process and paucity of means of ascertaining optimality [1,2]. To ameliorate this problem, Adeyeye and Oyawale [2] proposed an optimisation model for single flux design objective situation. The single flux design criterion optimisation approach was later extended to handle multiple flux design criteria situations [3,4]. Five multi-criteria optimisation approaches were suggested for

\footnotetext{
* Corresponding author: Adeyeye, Ademola David; Phone: +234 (0) 8029324 164; E-mail: ademola.adadeyeye@gmail.com Department of Industrial and Production Engineering, University of Ibadan, Ibadan, Nigeria. 
incorporating the various welding flux design objectives simultaneously, namely, weighted-sum scalarisation (WSS), desirability function (DF), compromise programming (CP), non-pre-emptive (NGP) and pre-emptive goal programming (PGP) $[3,4]$. The interest of the welding flux design community in the application of multi-criteria optimisation methods to welding flux design has been on the increase since the appearance of these papers. However, only the DF approach has received significant attention out of the five methods suggested for achieving optimal flux formulation [5-11].

Most of the papers that have appeared to date rarely consider the opinion and preferences of the WFS on the intensity of importance they attach to the various welding flux quality requirements [5, 11-14]. The investigators who did not completely overlook the preferences of the WFS presumed that all design criteria are of equal importance to the WFS [6-8, 13-14]. In the real-world engineering design situations, cases where design criteria are of varying degree of importance to stakeholders are encountered more frequently than the equal importance cases. One aspect of flux design that can significantly affect the result of flux optimisation is the incorporation of the preferences of the WFS in relation to the intensity of the importance they attach to the various design criteria. The elicitation and articulation of relative importance of design objectives as captured by criteria weights or preference indices has been of interest to researchers and engineering designers since the early 1960s and still remains a hot topic today [17-21]. It appears WFDs are unaware of means of elicitation and articulation of stakeholders' preferences. This could be the reason why WFS preferences are either overlooked or presumed to be the same for all criteria. Despite the plethora of articles in the literature, information on elicitation and articulation of WFS opinion and preferences as regards the degree of importance of the various flux quality objectives in welding flux design is sparse.

Allusion was made to the importance of incorporating the preferences of the WFS in terms of the intensity of the importance of the various flux quality characteristics in one of the earliest papers on application of multicriteria optimisation methods to welding flux design [3]. The relative importance of flux quality attributes was represented by weighting coefficient, for each attribute in the paper but how to articulate them was not presented. Adeyeye and Oyawale [4] used the pair-wise comparison approach to determine the values of the WFS' preference indices and incorporated them in the multi-criteria optimisation process using non-pre-emptive goal programming. Their work demonstrated the importance and relevance of incorporating the preference indices because the results obtained were significantly different from the one obtained when the flux quality attributes were presumed to be of equal importance. The implication is that welding flux obtained without the incorporation of WFS's preferences in terms of the degree of importance of attributes may not accurately reflect the desires of WFS. The incorporation of relative importance also allows for trade-off exploration by the use of different weight structures. The pair-wise comparison approach is however, too simplistic and does not account for inconsistency inherent in the comparison procedure. Adeyeye and Allu [22], addressed the problem of the inconsistency inherent in the pair-wise comparison method of quantifying WFS preferences by using the Analytical Hierarchy Process (AHP). The AHP has a means of measuring consistency, but their study was limited to criteria at the same level. Most of the studies done so far are limited to only one of the stages of the flux life cycle (see Table 1). For instance, some investigators limit their studies to the operational characteristics of the flux. This is only related to the time when the flux is used for welding, while some concentrate on the ability of the flux to produce weldment that will meet service requirements such as mechanical, microstructural and chemical properties [5-16]. Studies that consider the lifecycle of flux and incorporate the needs and desires of all WFS covering the entire lifecycle such as manufacturing, storage and transport, use, welder's health, and weld-metal quality simultaneously are not common in the open literature. The various welding flux design criteria and how the degree of importance was handled by various investigators as well as the multicriteria optimisation methods used are presented in Table 1.

It has been demonstrated that flux design objectives/quality attributes could be at different levels or hierarchy [3]. The primary, secondary and tertiary design objectives are at the first, second and third levels respectively. A primary welding flux design objective may be a bundle of secondary flux design objectives (i.e. consists of two or more subcriteria). Similarly, a secondary objective also may consist of two or more tertiary or sub-sub-criteria). The articulation of WFS preferences by identification and quantification of their opinions concerning the intensities of importance of each quality attribute relative to others has not received sufficient attention. There is therefore, a need for systematic approach of articulating WFS' opinion and preferences concerning all levels the flux design objectives including subcriteria and sub-sub-criteria. The goal of this paper is to propose an approach requiring a priori articulation of WFS' opinion concerning all levels (primary, secondary and tertiary) of design criteria to provide preference indices for welding flux design and performance optimisation. 
Table 1 Various welding flux Optimisation methods and incorporation of relative importance

\begin{tabular}{|c|c|c|c|c|c|}
\hline \multirow[t]{2}{*}{ Flux System } & \multicolumn{2}{|c|}{ Design Objectives } & \multirow{2}{*}{$\begin{array}{l}\text { Optimisation } \\
\text { Method }\end{array}$} & \multirow{2}{*}{$\begin{array}{l}\text { Relative } \\
\text { Importance }\end{array}$} & \multirow[t]{2}{*}{ [Reference] } \\
\hline & $\begin{array}{l}\text { Number } \\
\text { of } \\
\text { Objectives }\end{array}$ & Type of Objectives & & & \\
\hline $\begin{array}{l}\mathrm{CaO}-\mathrm{MgO}-\mathrm{CaF}_{2}- \\
\mathrm{Al}_{2} \mathrm{O}_{3}\end{array}$ & 8 & $\begin{array}{l}\mathrm{C}, \mathrm{Mn}, \mathrm{Si}, \mathrm{S}, \mathrm{P}, \mathrm{Ni}, \mathrm{O}_{2} \text { and } \mathrm{N}_{2} \\
\text { (chemical content) }\end{array}$ & NGP & $\begin{array}{l}\text { Different } \\
\text { weights } \\
\text { (pairwise } \\
\text { comparison) }\end{array}$ & [4] \\
\hline $\begin{array}{l}\mathrm{CaO}-\mathrm{MgO}-\mathrm{CaF}_{2-} \\
\mathrm{Al}_{2} \mathrm{O}_{3}\end{array}$ & 3 & $\begin{array}{l}\text { UTS, Toughness, \& Hardness } \\
\text { (mechanical properties) }\end{array}$ & DF & Overlooked & [5] \\
\hline $\begin{array}{l}\mathrm{CaO}-\mathrm{MgO}-\mathrm{CaF}_{2}- \\
\mathrm{Al}_{2} \mathrm{O}_{3}\end{array}$ & 6 & $\begin{array}{l}\Delta \mathrm{C}, \Delta \mathrm{Si}, \Delta \mathrm{Mn}, \Delta \mathrm{P}, \Delta \mathrm{S} \text { and } \\
\text { Hardness } \text { (element transfer } \\
\text { and mechanical properties) }\end{array}$ & DF & $\begin{array}{l}\text { Equal } \\
\text { importance }\end{array}$ & [7] \\
\hline $\begin{array}{l}\mathrm{CaO}-\mathrm{MgO}-\mathrm{CaF}_{2}- \\
\mathrm{Al}_{2} \mathrm{O}_{3}\end{array}$ & 5 & $\begin{array}{l}\text { C, Si, Mn, P and S } \\
\text { (mechanical properties) }\end{array}$ & DF & $\begin{array}{l}\text { Equal } \\
\text { importance }\end{array}$ & [6] \\
\hline $\begin{array}{l}\mathrm{SiO}_{2}-\mathrm{Al}_{2} \mathrm{O}_{3}-\mathrm{CaF}_{2}- \\
\mathrm{MnO}-\mathrm{TiO}_{2}-\mathrm{CaO}\end{array}$ & 3 & $\begin{array}{l}\text { UTS, Toughness, \& Cost } \\
\text { (mechanical properties \& cost) }\end{array}$ & DF & Overlooked & [8] \\
\hline NiO-MnO-MgO & 3 & $\begin{array}{l}\text { UTS, Toughness \& Hardness } \\
\text { (mechanical properties) }\end{array}$ & $\begin{array}{lr}\text { Hybrid grey, } \\
\text { fuzzy and } \\
\text { Taguchi }\end{array}$ & Overlooked & [21] \\
\hline $\mathrm{SiO}_{2}-\mathrm{NiO}-\mathrm{MnO}-\mathrm{MgO}$ & 3 & $\begin{array}{l}\text { UTS, Toughness \& Hardness } \\
\text { (mechanical properties) }\end{array}$ & $\begin{array}{l}\text { Hybrid Fuzzy } \\
\text { and Taguchi }\end{array}$ & Overlooked & [22] \\
\hline Slag-flux mixture & 4 & $\begin{array}{l}\text { UTS, Toughness, Elongation \& } \\
\text { Hardness }\end{array}$ & $\mathrm{DF}$ & Overlooked & [9] \\
\hline $\begin{array}{l}\mathrm{TiO}_{2}-\mathrm{SiO}_{2}-\mathrm{CaO}- \\
\mathrm{CaF}_{2}\end{array}$ & 3 & $\begin{array}{l}\text { UTS, Toughness \& Hardness } \\
\text { (mechanical properties) }\end{array}$ & DF & Equal weight & [10] \\
\hline $\begin{array}{l}\mathrm{CaO}-\mathrm{MgO}-\mathrm{CaF}_{2}- \\
\mathrm{Al}_{2} \mathrm{O}_{3}\end{array}$ & 8 & $\begin{array}{l}\text { AF, GBF, PF, FASP, SPF, YS, UTS, } \\
\text { Toughness (mechanical \& } \\
\text { microstructural properties) }\end{array}$ & $\mathrm{CP}$ & $\begin{array}{l}\text { Different } \\
\text { weights } \\
(\mathrm{AHP})\end{array}$ & [20] \\
\hline $\mathrm{CaF}_{2}-\mathrm{FeMn}-\mathrm{NiO}$ & 7 & $\begin{array}{l}\mathrm{P}, \mathrm{S}, \mathrm{UTS} \text {, Elongation, } \Delta \mathrm{Mn}, \Delta \mathrm{P}, \\
\Delta \mathrm{S} \quad \text { (element transfer \& } \\
\text { mechanical properties) }\end{array}$ & $\begin{array}{l}\text { Fuzzy logic } \\
\text { optimisation }\end{array}$ & Overlooked & [12] \\
\hline $\begin{array}{l}\mathrm{CaO}-\mathrm{MgO}-\mathrm{TiO}_{2-} \\
\mathrm{Al}_{2} \mathrm{O}_{3}\end{array}$ & 2 & $\begin{array}{l}\text { Hardness and Toughness } \\
\text { (mechanical properties) }\end{array}$ & $\begin{array}{l}\text { Taguchi } \\
\text { optimisation }\end{array}$ & $\begin{array}{l}\text { Mentioned } \\
\text { but did not } \\
\text { implement }\end{array}$ & [23] \\
\hline $\begin{array}{l}\mathrm{CaO}-\mathrm{SiO}_{2}-\mathrm{CaF}_{2}- \\
\mathrm{Al}_{2} \mathrm{O}_{3}\end{array}$ & 6 & $\begin{array}{l}\text { TC, TD, Density, WL, } \Delta \mathrm{H} \text {, and SP } \\
\text { (operational characteristics) }\end{array}$ & DF & Overlooked & {$[24]$} \\
\hline $\begin{array}{l}{\mathrm{MgO}-\mathrm{TiO}_{2}-\mathrm{SiO}_{2}-}_{\mathrm{Al}_{2} \mathrm{O}_{3}}\end{array}$ & 10 & $\begin{array}{l}\text { C, Si, P, S, Mn, Mo, Ti, Cr, GS and } \\
\text { Hardness (chemical content \& } \\
\text { mechanical properties) }\end{array}$ & DF & Equal weight & [13] \\
\hline $\begin{array}{l}\mathrm{CaO}-\mathrm{CaF}_{2}-\mathrm{SiO}_{2-}- \\
\mathrm{Al}_{2} \mathrm{O}_{3}\end{array}$ & 6 & $\begin{array}{l}\mathrm{D}, \mathrm{TD}, \mathrm{WL}, \mathrm{TC}, \Delta \mathrm{H} \text { and } \mathrm{SP} \\
\text { (operational characteristics) }\end{array}$ & DF & Equal weight & [25] \\
\hline $\begin{array}{l}\mathrm{CaO}_{-\mathrm{CaF}_{2}-\mathrm{SiO}_{2}-} \\
\mathrm{Al}_{2} \mathrm{O}_{3} \text { Flux System }\end{array}$ & 7 & $\begin{array}{l}\mathrm{C}, \mathrm{Si}, \mathrm{Mn}, \mathrm{Mo}, \mathrm{Cr}, \mathrm{GS} \text { and } \\
\text { Hardness (chemical content \& } \\
\text { mechanical properties) }\end{array}$ & DF & Equal weight & [26] \\
\hline $\begin{array}{l}\mathrm{CaO}-\mathrm{CaF}_{2}-\mathrm{SiO}_{2} \\
\mathrm{Al}_{2} \mathrm{O}_{3}\end{array}$ & 4 & $\mathrm{CA}, \mathrm{SA}, \mathrm{ST}$, and $\mathrm{AE}$ & DF & Overlooked & [27] \\
\hline $\begin{array}{l}\mathrm{CaO}-\mathrm{CaF}_{2}-\mathrm{TiO}_{2}- \\
\mathrm{SiO}_{2}\end{array}$ & 6 & $\begin{array}{l}\mathrm{D}, \mathrm{TD}, \mathrm{WL}, \mathrm{TC}, \Delta \mathrm{H} \text { and SP } \\
\text { (operational characteristics) }\end{array}$ & DF & Overlooked & [28] \\
\hline $\begin{array}{l}\mathrm{CaO}-\mathrm{CaF}_{2}-\mathrm{SiO}_{2} \\
\text { and } \mathrm{CaO}-\mathrm{TiO}_{2}-\mathrm{SiO}_{2}\end{array}$ & 4 & $\begin{array}{l}\mathrm{CA}, \mathrm{ST}, \mathrm{AE} \text {, and SA } \\
\text { (operational characteristics) }\end{array}$ & DF & Overlooked & [11] \\
\hline
\end{tabular}

$\mathrm{AE}=$ Adhesion energy, $\mathrm{AF}=$ Acicular ferrite, $\mathrm{CA}=$ Contact area, $\mathrm{FASP}=$ Ferrite with aligned second phase, $\mathrm{GBF}=\mathrm{Grain}$ boundary ferrite, GS=Grain size, $\mathrm{PF}=$ Polygonal ferrite, $\mathrm{SA}=$ Spreading area, $\mathrm{SP}=$ Spread area, $\mathrm{SPF}=$ Side plate ferrite, $\mathrm{ST}=$ Surface tension, $\mathrm{TC}=\mathrm{Thermal}$ conductivity, $\mathrm{TD}=\mathrm{Thermal}$ diffusivity, UTS=Ultimate tensile strength, $\mathrm{WL}=$ Weight loss, YS=Yield strength, $\Delta \mathrm{H}=$ Change in enthalpy, 


\section{Proposed approach}

\subsection{Description of welding flux design problem:}

Welding flux design problem has the following properties (i) There is a hierarchy of criteria. At the highest level is a set of main or primary criteria each or some of which have a set of secondary/sub-criteria at the second level. A subcriterion may also consist of a finite set of tertiary/sub-sub-criteria (ii) the criteria express the desires or requirements of various stakeholders and span through the entire life cycle of the flux from manufacture, storage, use of flux in welding, disposal and handling of by-products and functionality of the welded component when put in service (iii) the criteria are of varying intensity of importance to the stakeholders. The degree of importance is incorporated in the process of determining the optimum flux (iv) there is a finite set of flux ingredients from which the flux is to be made. The scope of this study is limited to a situation where a priori articulation of the opinion/preferences of the stakeholders concerning all levels of criteria (Primary, secondary and tertiary criteria) is possible. In situations where a priori articulation of WFS' preferences is not possible, interactive or posteriori methods may be used by the WFD. However, the interactive and posteriori methods are beyond the scope of this work. Generally, the problem of the WFD is to determine the right proportion of the various flux ingredients that best fulfil the numerous criteria and preferences of WFS in terms of the relative importance attached to each criterion. This is a daunting problem because the criteria are more often than not conflicting, non-commensurable in dimensions and of different order of magnitude in addition to the varying degree of importance and simultaneous handling of all levels of criteria (main criteria, sub-criteria and subsub-criteria). The simultaneous handling of all criteria in the hierarchy and computation of weighting coefficients that reflect the relative importance of all criteria in arriving at the optimum flux is the focus of this paper. Many methods exist for weighting coefficient determination but the Analytical Hierarchy Process (AHP) will be used in this study. First, the AHP is discussed in section 2.2 followed by the procedural steps for handling all criteria in the hierarchy in section 2.3 .

\subsection{Brief description of the AHP}

The AHP was proposed by Saaty [29, 30]. The original AHP and the successive developments have found wide applications. The details of the AHP are available in the literature hence we present only a brief description. The AHP provides means of eliciting judgements that reflects the opinions, feelings, concerns or preferences on the various criteria from stakeholders. The criteria are subjectively compared in pairs and the judgements of stakeholders are represented with meaningful numbers using Saaty's scale (see Table 2).

Table 2 Saaty Scale for Relative Importance

\begin{tabular}{|l|l|}
\hline Definition & Intensity of importance \\
\hline Equal importance & 1 \\
\hline Moderate importance & 3 \\
\hline Strong importance & 5 \\
\hline Very strong importance & 7 \\
\hline Extreme importance & 9 \\
\hline Intermediate importance & $2,4,6,8$ \\
\hline Reciprocals & $\begin{array}{l}\text { If criterion } i \text { has one of the above numbers, say } k \text { assigned to it when compared with } \\
\text { criterion } j \text {, then } j \text { has the reciprocal } 1 / k \text { when compared with } i .\end{array}$ \\
\hline
\end{tabular}

These numbers are then used to obtain weights that represent the relative importance of the criteria. The AHP also provides measures of judgement consistency. The procedure of AHP is as follows.

i. $\quad$ Construct the pairwise comparison matrix

ii. $\quad$ Normalise the resulting matrix

iii. Find the average values of each row to get the weighted average which represent the criterion

iv. Calculate the consistency index, $C I=\left(\lambda_{\max }-n\right) / n-1$

Where $\lambda_{\max }$ is the largest eigenvalue, and $\mathrm{n}$ is the number of criteria

v. Calculate the consistency ratio, $\mathrm{CR}=\mathrm{CI} / \mathrm{RI}$

Where RI is random index value read from the random consistency index table 
vi. If $\mathrm{CR}<0.1(10 \%)$ then the judgement is consistent and accept the weights as preference indices otherwise go back to step (i) and repeat till acceptable consistency is attained.

\subsection{Procedure for incorporating all levels of criteria}

\subsubsection{Step 1: Identify welding flux stakeholders (WFS)}

Identify all people (e.g. welders, users of welded products, etc...) and organizations such as firms that use the welding flux and regulatory agencies that may be affected at each lifecycle stage of the welding flux. In the case of organisations, there may be need to identify the internal stakeholders as well.

\subsubsection{Step 2: Identify of all design criteria}

Identify the needs, concerns, requirements and specifications of the WFS listed in step 1 and generate the welding flux design objectives. Structure the welding flux design problem as a hierarchy of criteria. Identify the set, $\mathrm{P}$ of primary/main criteria. Unbundle each primary criterion to identify the set $S_{a}$ of secondary criteria for each a $\in \mathrm{P}$. Also, unbundle each secondary criterion to identify the set $T_{a b}$ of tertiary criteria for each $\mathrm{b} \in S_{a}$. Continue to unbundle till the lowest level, where the criterion could not be further unbundled (see the Fig. below).

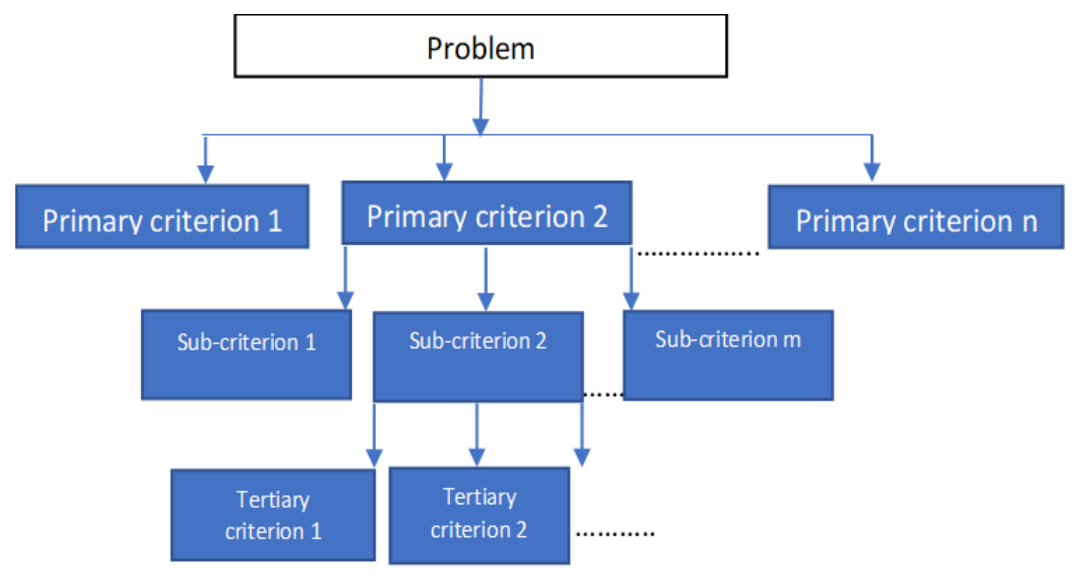

Figure 1 Hierarchy of criteria

\subsubsection{Step 3: Determine the weighting coefficient for primary criteria}

Determine the weight $w_{a}$, for each primary criterion $a \in \mathrm{P}$ to reflect its relative importance using the AHP. Observe that,

$\sum_{a \in P} w_{a}=1$

\subsubsection{Step 4: Determine the weighting coefficient for secondary criteria}

Determine the weights $\left(w_{b}\right)$ for each secondary criterion $\left(b \in S_{a}\right)$ using AHP. Note that the $w_{b}$ only compare subcriteria that are under the same primary criterion. It bears no relationship with sub-criterion that is under a different primary criterion. Also, observe that

$\sum_{b \in S_{a}} w_{b}=1$ for each $a \in P$

\subsubsection{Step 5: Determine the weighting coefficient for tertiary criteria}

Determine the local weights $w_{c}^{L}$ for each tertiary criterion $c \in T_{a b}$ respectively, for each $a \in \mathrm{P}$ and $b \in S_{a}$ using AHP. Observe that the local weights give the relative importance of tertiary criteria that are under the same sub-criterion. They bear no relationship with sub-sub-criteria that are under a different sub-criterion.

Note that

$\sum_{c \in T_{a b}} w_{c}^{L}=1$ for each $a \in P$ and $b \in S_{a}$ 
The weight, $w_{c}^{L}$ is the local weight of each tertiary criterion relative to other criteria within the same sub-criterion.

\subsubsection{Step 6: Compute the global weight}

Compute the value of the global weight, $w_{c}^{G}$. This is given by:

$w_{c}^{G}=w_{a} w_{b} w_{c}^{L}$ for each $a \in P, b \in S_{a}, c \in T_{a b}$

If primary criterion ' $a$ ' cannot be unbundled, then

$w_{a}=w_{c}^{L}=w_{c}^{G}$

Similarly, if a secondary criterion ' $b$ ' cannot be further unbundled then,

$w_{c}^{G}=w_{a} w_{b}$

Observe that the global weight $\left(w_{c}^{G}\right)$ unlike the local weight $\left(w_{c}^{L}\right)$, reflects the relative importance of tertiary criterion c, in relation to all the other criteria. It is a normalised weighting coefficient, hence,

$\sum_{a \in P} \sum_{b \in S_{a}} \sum_{c \in T_{a b}} w_{c}^{G}=\sum_{a \in P} w_{a}=1$

Also,

$\sum_{b \in S_{a}} \sum_{c \in T_{a b}} w_{c}^{G}=w_{a} \quad$ for each $a \in P$

Normalised weights are preferred because they reflect the relative importance of design or evaluation criteria proportionately and make them easily comparable. However, ideal weights are also used and is given by Thipparat and Thaseepetch [31];

$w_{c}^{I}=w_{c}^{G} / \max \left(w_{c}^{G}\right)$ for each $a \in P, b \in S_{a}, c \in T_{a b}$

\subsubsection{Step 7: Incorporate the weighting coefficients in the optimisation model}

The set of global weights, $\left(\mathbf{W}_{\mathbf{c}}\right)$, consisting of the $w_{c}^{G} s$ represents the weight structures or preference indices and are now ready to be incorporated into the solution process as illustrated in Equations (12-14) below. These examples are illustrative and not exhaustive because it is a near impossibility to apply a single optimisation method for all welding flux design problems. The welding flux design objectives and parameters vary from situation to situation, hence different optimisation methods need to be used for different welding flux design problems. Three out of the multicriteria optimisation methods suggested by Adeyeye and Oyawale [3] are used to illustrate the use of the global weights. Incorporation of WFS's preferences is possible for any multi-criteria optimisation method the WFD may consider as the most suitable for his/her welding flux design situation.

(a) Weighted-sum scalarization/Linear aggregation method: The flux design problem is transformed into a single combinational problem as Equation (12) below

$\operatorname{Max} F(x)=\sum_{c \in T_{a b}} w_{c}^{G} f_{c}(x)$,

subject to,

$$
g_{m}(x)=, \leq, \geq q_{m}
$$


Where, $F(x)$ is the weighted sum or linear aggregate of the lowest level criteria functions, $f_{c}(x)$ for all primary criteria. Also, $w_{c}^{G}>0, \forall c$ and $f_{c}(x)$ is mathematical expression for the lowest level criterion "c" in terms of the flux ingredients and $g_{m}(x)$ and $q_{m}$ are the function and the right hands side of the $m^{t h}$ constraint respectively. Observe that the $f_{c}(x) \mathrm{s}$ were the only functions used because the level of the achievement of lowest level criteria determines the level of the achievement of the higher-level criteria.

(b) Non-linear aggregation method: The transformation of the problem into a single combinational problem is achieved through non-linear aggregation method. The commonest of this approach is the Desirability Function method as shown in Equation (13) below.

Maximise, $D=\left(\prod_{c \in T_{a b}} d_{c}^{w_{c}^{G}}\right)^{1 / \sum_{c \in T_{a b}} w_{c}^{G}}$

subject to,

$$
g_{m}(x)=, \leq, \geq q_{m}
$$

Where, $D$ and $d_{c}$ are the overall and the individual desirability of the lowest level criteria, respectively.

(c) Distance-function methods: Multi-criteria methods such as goal programming, reference point methods and compromise programming are based on distance measures. We illustrate with compromise programming as in Equation (14) below

Minimise, $D L_{p}=\left[\sum_{c \in T_{a b}}\left(w_{c}^{G}\right)^{p}\left(\frac{f_{c}^{*}(x)-f_{c(x)}}{f_{c}^{*}(x)-f_{c}^{* *}(x)}\right)^{p}\right]^{1 / p}$

subject to,

$$
g_{m}(x)=, \leq, \geq q_{m}
$$

Where, $D L_{P}$ and $p$ are the overall distance measure for $p$ while $p$ is a real number in the closed interval $[0, \infty]$.

\section{Numerical example}

In order to demonstrate the application of the proposed approach for determination for weighting coefficient, a life cycle welding flux design situation for SMAW presented in the literature was used [3]. As a first step, key stakeholders were identified. Based on their needs, concerns, requirements and specifications of WFS all the primary criteria (P), sub-criteria $\left(\boldsymbol{S}_{\boldsymbol{a}}\right)$ and sub-sub-criteria $\left(\boldsymbol{T}_{\boldsymbol{a} \boldsymbol{b}}\right)$ were also identified. The weights $w_{a}, w_{b}$ and $w_{c}^{L}$ for the primary, secondary and tertiary criteria were computed using AHP described in Section 2.2 and step 1 through step 5 of Section 2.3 . Finally, the global weights $\left(w_{c}^{G}\right)$ and ideal weights $\left(w_{c}^{I}\right)$ of all the lowest level/tertiary criteria were determined using Equations. (6), (8) and (11).

\section{Results and discussion}

The 5 primary criteria that are of relevance and importance to the various WFS were weld-metal quality, health and environmental benign, manufacturability, storage and operational performance with each having 4, 3, 3, 3 and 8 subcriteria respectively (see Table 3). The primary criterion, weld-metal quality has 4 sub-criteria, namely; chemical composition, microstructural features, mechanical performance and weld-bead geometry each having 4, 6, 5, and 4 subsub-criteria respectively. The sub-criteria with their respective lower-level criteria for all primary criteria are presented in Table 3. Overall, there are 5 primary criteria, 21 sub-criteria and 25 sub-sub-criteria. Out of the 21 sub-criteria, 6 were further unbundled into 25 tertiary criteria while the remaining 15 sub-criteria could not be unbundled further, hence they are the lowest level criteria. 
Table 3 Welding Flux Design Criteria Hierarchy for SMAW

\begin{tabular}{|c|c|c|c|}
\hline $\begin{array}{l}\text { Welding Flux } \\
\text { Stakeholders }\end{array}$ & $\begin{array}{l}\text { Primary criteria, } P \text { (No of } \\
\text { next lower-level criteria) }\end{array}$ & $\begin{array}{l}\text { Secondary criteria (No of next } \\
\text { lower-level criteria) }\end{array}$ & Tertiary criteria \\
\hline \multirow{19}{*}{$\begin{array}{l}\text { User of welded } \\
\text { product, } \\
\text { Regulatory } \\
\text { agencies, } \\
\text { Professional } \\
\text { bodies... }\end{array}$} & \multirow[t]{19}{*}{ Weld-metal quality (4) } & \multirow[t]{4}{*}{ Chemical composition (4) } & Chromium \\
\hline & & & Manganese \\
\hline & & & Carbon \\
\hline & & & Diffusible Hydrogen \\
\hline & & \multirow[t]{6}{*}{ Microstructural features (6) } & Ferrite Number \\
\hline & & & Acicular Ferrite \\
\hline & & & Bainite \\
\hline & & & Inclusion Volume Fraction \\
\hline & & & Inclusion Size \\
\hline & & & Inclusion Number Density \\
\hline & & \multirow[t]{5}{*}{ Mechanical performance (5) } & Yield Strength \\
\hline & & & Ultimate Tensile Strength \\
\hline & & & Charpy Impart Strength \\
\hline & & & Hardness \\
\hline & & & Elongation \\
\hline & & \multirow[t]{4}{*}{ Weld bead geometry (4) } & Penetration \\
\hline & & & Reinforce \\
\hline & & & Bead Width \\
\hline & & & Dilution \\
\hline \multirow{7}{*}{$\begin{array}{l}\text { Occupational } \\
\text { health and safety } \\
\text { agencies, } \\
\text { welders.... }\end{array}$} & \multirow{7}{*}{$\begin{array}{l}\text { Health and environmental } \\
\text { benign (3) }\end{array}$} & \multirow[t]{3}{*}{ Fume (3) } & Fume Generation Rate \\
\hline & & & Particle Number \\
\hline & & & Mass Distribution \\
\hline & & Odour (None) & - \\
\hline & & \multirow[t]{3}{*}{ Toxicity (3) } & Hexavalent Chromium $\left(\mathrm{Cr}^{6+}\right)$ \\
\hline & & & Manganese \\
\hline & & & Nickel \\
\hline \multirow[t]{3}{*}{ Manufacturer } & \multirow[t]{3}{*}{ Manufacturability (3) } & Extrudability (None) & - \\
\hline & & Bonding (None) & - \\
\hline & & Uniform Mixing (None) & - \\
\hline \multirow{3}{*}{$\begin{array}{l}\text { Manufacturer, } \\
\text { fabricator, } \\
\text { construction } \\
\text { firm, }\end{array}$} & \multirow[t]{3}{*}{ Storage (3) } & Durability of coating (None) & - \\
\hline & & Moisture Pickup (None) & - \\
\hline & & Shelf-life (None) & - \\
\hline \multirow{8}{*}{$\begin{array}{l}\text { Welder, } \\
\text { fabricator, } \\
\text { construction/ass } \\
\text { embly firm.... }\end{array}$} & \multirow{8}{*}{$\begin{array}{l}\text { Operational performance } \\
(8)\end{array}$} & Arc striking (None) & - \\
\hline & & Arc stability (None) & - \\
\hline & & Penetration Control (None) & - \\
\hline & & Spatter (None) & - \\
\hline & & Slag control (None) & - \\
\hline & & Slag Detachability (None) & - \\
\hline & & Deposition Rate (None) & - \\
\hline & & Electrode Overheating (None) & - \\
\hline
\end{tabular}


There are 40 lowest level criteria all together consisting of 15 sub-criteria that could not be unbundled and the 25 tertiary criteria. The pairwise comparison matrix for the 5 primary criteria with their respective weights and consistency ratio are presented in Table 4. The consistency ratio of 0.0667 (i.e. CR $=6.67 \%$ ) which is $<0.1$ (i.e. $10 \%$ ) indicates that the judgement made during the pairwise comparison is consistent and should be accepted. The respective weights $\left(w_{a}\right)$ for weld-metal quality, health and environmental benign, manufacturability, storage and operational are $0.1108,0.0706,0.1836,0.2700$ and 0.3650 . Based on their weights, operational characteristic, storage performance, manufacturability, weld-metal quality and welders health are $1^{\text {st }}, 2^{\text {nd }}, 3^{\text {rd }}, 4^{\text {th }}$ and $5^{\text {th }}$ in order of intensity of importance respectively. The weights sum up to 1 or $100 \%$ because the weights are normalised (see Table 4 ). Since the primary criteria are bundles of lower-level criteria, the weighting coefficients won't be able to give desired results without taking the lower-level criteria in to consideration. The weighting coefficients $\left(w_{b}\right)$ of the 4 sub-criteria (chemical composition, microstructural features, mechanical performance and weld-bead) under the primary criterion weld-metal quality are $(0.3554,0.3867,0.1221$ and 0.1357$)$ respectively (see Table 5$)$. The local weights $\left(w_{c}^{L}\right)$ for sub-sub-criteria under the sub-criterion chemical composition are chromium (0.6073), manganese (0.2277), carbon (0.1012) and diffusible hydrogen content ( 0.0639$)$ as indicated in Table 6 . The sum of the local weights of tertiary criteria under the sub-criteria chemical composition is 1 .

Table 4 Pairwise comparison of primary criteria and weighting coefficient

\begin{tabular}{|l|l|l|c|c|c|l|}
\hline Flux Quality & $\begin{array}{l}\text { Weld- } \\
\text { metal } \\
\text { Quality }\end{array}$ & $\begin{array}{l}\text { Environmental } \\
\text { benign }\end{array}$ & Manufacturability & Storage & $\begin{array}{l}\text { Operational } \\
\text { performance }\end{array}$ & $\begin{array}{l}\text { Weight } \\
\left(\boldsymbol{w}_{\boldsymbol{a}}\right)\end{array}$ \\
\hline $\begin{array}{l}\text { Weld-metal } \\
\text { Quality }\end{array}$ & 1 & 2 & $1 / 3$ & $1 / 4$ & $1 / 2$ & 0.1108 \\
\hline $\begin{array}{l}\text { Environmental } \\
\text { Benign }\end{array}$ & $1 / 2$ & 1 & $1 / 3$ & $1 / 3$ & $1 / 4$ & 0.0706 \\
\hline Manufacturability & 3 & 3 & 1 & $1 / 2$ & $1 / 3$ & 0.1836 \\
\hline Storage & 4 & 3 & 2 & 1 & $1 / 2$ & 0.2700 \\
\hline $\begin{array}{l}\text { Operational } \\
\text { performance }\end{array}$ & 2 & 4 & 3 & 2 & 1 & 0.3650 \\
\hline \\
[Note: Equations. (1) and (2) in Section 2.2]
\end{tabular}

Table 5 Pairwise comparison of sub-criteria under weld-metal quality with weights

\begin{tabular}{|l|l|l|l|l|l|}
\hline Sub-criteria & $\begin{array}{l}\text { Chemical } \\
\text { composition }\end{array}$ & $\begin{array}{l}\text { Microstructural } \\
\text { features }\end{array}$ & $\begin{array}{l}\text { Mechanical } \\
\text { performance }\end{array}$ & Weld-bead & Weight $\left(\boldsymbol{w}_{\boldsymbol{b}}\right)$ \\
\hline Chemical composition & 1 & 1 & 2 & 4 & 0.3554 \\
\hline Microstructural features & 1 & 1 & 3 & 4 & 0.3867 \\
\hline Mechanical performance & \multicolumn{1}{|c|}{$1 / 2$} & $1 / 3$ & 1 & $1 / 2$ & 0.1221 \\
\hline Weld-bead & \multicolumn{2}{|c|}{$1 / 4$} & 2 & 1 & 0.1357 \\
\hline \\
[Note: Equations. (1) and (2) in Section 2.2]
\end{tabular}

Table 6 Pairwise comparison of sub-sub-criteria under sub-criteria chemical composition with weights

\begin{tabular}{|l|c|l|l|l|l|}
\hline Sub-criteria & Chromium & Manganese & Carbon & Diffusible Hydrogen & Weight $\left(\boldsymbol{w}_{c}^{L}\right)$ \\
\hline Chromium & 1 & 4 & 6 & 7 & 0.6073 \\
\hline Manganese & $1 / 4$ & 1 & 3 & 4 & 0.2277 \\
\hline Carbon & $1 / 6$ & $1 / 3$ & 1 & 2 & 0.1012 \\
\hline Diffusible Hydrogen & $1 / 7$ & $1 / 4$ & $1 / 2$ & 1 & 0.0639 \\
\hline
\end{tabular}


The result for all levels of criteria is presented in Table 7. The local weight, $\left(w_{c}^{L}\right)$ compares the tertiary criterion ' $c$ ' with other criteria under the same secondary criterion. Its practical importance is for the computation of the global weight. The global weights $\left(w_{c}^{G}\right)$ of lowest level criteria reflect the relative importance of all the criteria regardless of the primary or secondary criteria they belong to (see Table 7). In terms of relative importance, moisture pickup, extrudability and slag detachability are ranked $1^{\text {st }}, 2^{\text {nd }}$ and $3^{\text {rd }}$ respectively by the values of $\left(w_{c}^{G}\right)$ while fume generation, dilution and charpy impart strength are the $38^{\text {th }}, 39^{\text {th }}$ and $40^{\text {th }}$ respectively. The global weights represent the WFS's preference indices which are ready for use in the optimisation model selected for use by the WFD as illustrated in Equations. (12-14). The ideal weight $\left(w_{c}^{I}\right)$ may also be use but its drawback is that it not easy to compare the criteria as in the case of global weights. The performance of the flux on the primary design criteria are determined by the tertiary or lowest level criteria. To achieve desired quality levels on the primary criteria, the WFD need to focus more on the lowest level criteria.

It is pertinent to note that, although operational performance is the most important among the primary criteria, the first 2 most important lowest level criteria (moisture pickup and extrudability) are not under it. The most important tertiary criteria which is moisture pickup is under storage performance while the second most important which is extrudability is under ease of manufacture/manufacturability. However, by the time the weights of all the tertiary criteria under each primary criterion are added together, we see that the sum is equal to weight of the primary criterion. For instance, the sum of the global weights $\left(w_{c}^{G}\right)$ of all the tertiary criteria (extrudability, bonding and uniform mixing) under the primary criterion manufacturability is $(0.11627+0.04783+0.01950=0.1836)$ which is the same as weight of manufacturability (see Table 7). This is true of all the other criteria since the tertiary criteria determine the secondary criteria which in turn determines the primary criteria. The proposed procedure is useful for any welding flux design environments in which the quality attributes or design objectives can be unbundled into secondary and tertiary criteria. However, it is limited to design situations where a priori articulation of WFSs preferences concerning all levels of criteria is possible.

Table 7 Weight Structure for Primary, Secondary and Tertiary Criteria

\begin{tabular}{|c|c|c|c|c|c|c|c|c|}
\hline \multicolumn{2}{|l|}{ Primary criteria } & \multicolumn{2}{|c|}{ Secondary criteria } & \multicolumn{5}{|c|}{ Tertiary criteria } \\
\hline Criteria name & $w_{a}$ & $\begin{array}{l}\text { Criteria } \\
\text { name }\end{array}$ & $w_{b}$ & Criteria name & $w_{c}^{L}$ & $w_{c}^{G}$ & $w_{c}^{I}$ & Rank \\
\hline \multirow[t]{12}{*}{ Weld-metal quality } & \multirow[t]{12}{*}{0.1108} & \multirow[t]{5}{*}{ Composition } & \multirow[t]{5}{*}{0.3554} & Chromium & 0.6073 & 0.02392 & 0.13674 & $12^{\text {th }}$ \\
\hline & & & & Manganese & 0.2277 & 0.00897 & 0.05126 & $20^{\text {th }}$ \\
\hline & & & & Carbon & 0.1012 & 0.00399 & 0.02279 & $29^{\text {th }}$ \\
\hline & & & & $\begin{array}{l}\text { Diffusible } \\
\text { Hydrogen }\end{array}$ & 0.0639 & 0.00252 & 0.01439 & $33^{\text {rd }}$ \\
\hline & & & & $\begin{array}{l}\text { TOTAL } \\
{\left[\sum_{c \in T_{a b}} w_{c}^{L}\right]}\end{array}$ & 1 & & & \\
\hline & & \multirow[t]{7}{*}{$\begin{array}{l}\text { Microstruct } \\
\text { ural features }\end{array}$} & \multirow[t]{7}{*}{0.3867} & $\begin{array}{l}\text { Ferrite } \\
\text { Number }\end{array}$ & 0.4086 & 0.01751 & 0.10008 & $14^{\text {th }}$ \\
\hline & & & & $\begin{array}{l}\text { Acicular } \\
\text { Ferrite }\end{array}$ & 0.1091 & 0.00467 & 0.02672 & $25^{\text {th }}$ \\
\hline & & & & Bainite & 0.2587 & 0.01108 & 0.06336 & $18^{\text {th }}$ \\
\hline & & & & $\begin{array}{l}\text { Inclusion } \\
\text { Volume } \\
\text { Fraction }\end{array}$ & 0.079 & 0.00338 & 0.01935 & $32^{\text {nd }}$ \\
\hline & & & & Inclusion Size & 0.0859 & 0.00368 & 0.02104 & $31^{\text {st }}$ \\
\hline & & & & $\begin{array}{l}\text { Inclusion } \\
\text { Number } \\
\text { Density }\end{array}$ & 0.0586 & 0.00251 & 0.01435 & $34^{\text {th }}$ \\
\hline & & & & $\begin{array}{l}\text { TOTAL } \\
{\left[\sum_{c \in T_{a b}} w_{c}^{L}\right]}\end{array}$ & 1 & & & \\
\hline
\end{tabular}




\begin{tabular}{|c|c|c|c|c|c|c|c|c|}
\hline & & Mechanical & 0.1221 & Yield Strength & 0.352 & 0.00476 & 0.02722 & $24^{\text {th }}$ \\
\hline & & performance & & $\begin{array}{l}\text { Ultimate } \\
\text { Tensile } \\
\text { Strength }\end{array}$ & 0.2999 & 0.00406 & 0.02319 & $28^{\text {th }}$ \\
\hline & & & & $\begin{array}{l}\text { Charpy Impart } \\
\text { Strength }\end{array}$ & 0.0433 & 0.00059 & 0.00335 & $40^{\text {th }}$ \\
\hline & & & & Hardness & 0.1718 & 0.00232 & 0.01329 & $35^{\text {th }}$ \\
\hline & & & & Elongation & 0.133 & 0.0018 & 0.01029 & $36^{\text {th }}$ \\
\hline & & & & $\begin{array}{l}\text { TOTAL } \\
{\left[\sum_{c \in T_{a b}} w_{c}^{L}\right]}\end{array}$ & 1 & & & \\
\hline & & Weld bead & 0.1357 & Penetration & 0.5633 & 0.00847 & 0.04842 & $15^{\text {th }}$ \\
\hline & & & & Reinforce & 0.2798 & 0.00421 & 0.02405 & $27^{\text {th }}$ \\
\hline & & & & Bead Width & 0.0993 & 0.00149 & 0.00854 & $37^{\text {th }}$ \\
\hline & & & & Dilution & 0.0576 & 0.00087 & 0.00495 & $39^{\text {th }}$ \\
\hline & & {$\left[\sum_{b \in S_{a}} \boldsymbol{w}_{b}\right]=\mathbf{1}$} & & {$\left[\sum_{c \in T_{a b}} \boldsymbol{w}_{c}^{L}\right]=\mathbf{1}$} & & {$[0.1108]$} & & \\
\hline $\begin{array}{l}\text { Health and } \\
\text { environmental }\end{array}$ & 0.0706 & Fume & 0.2431 & $\begin{array}{l}\text { Fume } \\
\text { Generation } \\
\text { Rate }\end{array}$ & 0.0637 & 0.00109 & 0.00625 & $38^{\text {th }}$ \\
\hline & & & & $\begin{array}{l}\text { Particle } \\
\text { Number }\end{array}$ & 0.2674 & 0.00459 & 0.02624 & $26^{\text {th }}$ \\
\hline & & & & $\begin{array}{l}\text { Mass } \\
\text { Distribution }\end{array}$ & 0.6689 & 0.01148 & 0.06563 & $17^{\text {th }}$ \\
\hline & & & & $\begin{array}{l}\text { TOTAL } \\
{\left[\sum_{c \in T_{a b}} w_{c}^{L}\right]}\end{array}$ & 1 & & & \\
\hline & & Odour & 0.1181 & - & - & 0.00834 & 0.04766 & $23^{\text {rd }}$ \\
\hline & & Toxicity & 0.6389 & $\begin{array}{l}\text { Hexavalent } \\
\text { Chromium } \\
\left(\mathrm{Cr}^{6+}\right)\end{array}$ & 0.7235 & 0.03263 & 0.18655 & $11^{\text {th }}$ \\
\hline & & & & Manganese & 0.1932 & 0.00871 & 0.04982 & $20^{\text {th }}$ \\
\hline & & & & Nickel & 0.0833 & 0.00376 & 0.02148 & $30^{\text {th }}$ \\
\hline & & {$\left[\sum_{b \in S_{a}} \boldsymbol{w}_{b}\right]=\mathbf{1}$} & & {$\left[\sum_{c \in T_{a b}} \boldsymbol{w}_{c}^{L}\right]=\mathbf{1}$} & & {$[0.0706]$} & & \\
\hline Manufacturability & 0.1836 & $\begin{array}{l}\text { Extrudabilit } \\
\text { y }\end{array}$ & 0.6333 & - & - & 0.11627 & 0.66468 & $2^{\text {nd }}$ \\
\hline & & Bonding & 0.2605 & - & - & 0.04783 & 0.27341 & $7^{\text {th }}$ \\
\hline & & $\begin{array}{l}\text { Uniform } \\
\text { Mixing }\end{array}$ & 0.1062 & - & - & 0.01950 & 0.11146 & $13^{\text {th }}$ \\
\hline & & {$\left[\sum_{b \in S_{a}} \boldsymbol{w}_{b}\right]=\mathbf{1}$} & & & & [0.1836] & & \\
\hline Storage & 0.27 & $\begin{array}{l}\text { Durability of } \\
\text { coating }\end{array}$ & 0.2299 & - & - & 0.06207 & 0.35484 & $6^{\text {th }}$ \\
\hline & & $\begin{array}{l}\text { Moisture } \\
\text { Pickup }\end{array}$ & 0.6479 & - & - & 0.17493 & 1 & $1^{\text {st }}$ \\
\hline & & Shelf-life & 0.1222 & - & - & 0.03299 & 0.18861 & $10^{\text {th }}$ \\
\hline & & {$\left[\sum_{b \in S_{a}} w_{b}\right]=1$} & & & & {$[0.2700]$} & & \\
\hline
\end{tabular}




\begin{tabular}{|c|c|c|c|c|c|c|c|c|}
\hline \multirow[t]{9}{*}{$\begin{array}{l}\text { Operational } \\
\text { performance }\end{array}$} & \multirow[t]{9}{*}{0.365} & Arc striking & 0.2053 & - & - & 0.07493 & $\begin{array}{l}0.42836 \\
1\end{array}$ & $4^{\text {th }}$ \\
\hline & & Arc stability & 0.0934 & - & - & 0.03409 & 0.19488 & $9^{\text {th }}$ \\
\hline & & $\begin{array}{l}\text { Penetration } \\
\text { Control }\end{array}$ & 0.0423 & - & - & 0.01544 & 0.08826 & $15^{\text {th }}$ \\
\hline & & Spatter & 0.0381 & - & - & 0.01391 & 0.07950 & $16^{\text {th }}$ \\
\hline & & Slag control & 0.0257 & - & - & 0.00938 & 0.05362 & $19^{\text {th }}$ \\
\hline & & $\begin{array}{l}\text { Slag } \\
\text { Detachabilit } \\
\text { y }\end{array}$ & 0.3142 & - & - & 0.11468 & 0.65558 & $3^{\text {rd }}$ \\
\hline & & $\begin{array}{l}\text { Deposition } \\
\text { Rate }\end{array}$ & 0.1709 & - & - & 0.06238 & $\begin{array}{l}0.35658 \\
5\end{array}$ & $5^{\text {th }}$ \\
\hline & & $\begin{array}{l}\text { Electrode } \\
\text { Overheating }\end{array}$ & 0.11 & - & - & 0.04015 & $\begin{array}{l}0.22951 \\
6\end{array}$ & $8^{\text {th }}$ \\
\hline & & \multicolumn{2}{|c|}{$\left[\sum_{b \in S_{a}} w_{b}\right]=\mathbf{1}$} & & & {$[0.3650]$} & & \\
\hline \multicolumn{2}{|l|}{$\sum_{a \in P} w_{a}=1$} & & & \multicolumn{3}{|c|}{$\sum_{a \in P} \sum_{b \in S_{a}} \sum_{c \in T_{a b}} \boldsymbol{w}_{c}^{G}=\mathbf{1}$} & & \\
\hline
\end{tabular}

\section{Conclusion}

A framework that helps welding flux designer to articulate and incorporate the opinions of stakeholders concerning the intensities of the importance of multiple flux design criteria has been developed. The procedure is suitable for welding flux design situations in which the primary design objectives are unbundled into secondary and tertiary objectives. The computed global weights allow all the lowest level criteria to reflect the relative importance attached to each criterion in agreement with stakeholders' opinion. The incorporation of the global weights into the optimisation model ensures that the flux so designed gives the welding flux designer maximum realisation of the flux design objectives. It is limited to flux design situations where a priori articulation of stakeholder's opinions is possible.

\section{Compliance with ethical standards}

\section{Acknowledgments}

The authors acknowledge the support of the Department of Industrial and Production Engineering, University of Ibadan, Nigeria for providing the enabling environment for carrying out the research.

\section{Disclosure of conflict of interest}

The authors declare that there is no conflict of interest in the preparation and submission of this paper.

\section{References}

[1] Adeyeye AD, Oyawale FA. "Mixture experiments and their applications in welding flux design". Journal of the Braz. Soc. of Mech. Sci. \& Eng. 2008; 30(4): 319-326.

[2] Adeyeye AD, Oyawale FA. "Weld-metal property optimization from flux ingredients through mixture experiments and mathematical programming approach". Materials Research. 2009; 12(3): 339-343.

[3] Adeyeye AD, Oyawale FA. "Multi-objective methods for welding flux performance optimization". RMZ - Materials and Geoenvironment. 2010; 57(2): 251-270.

[4] Adeyeye AD, Oyawale FA. "Optimisation of weld-metal chemical composition from welding-flux ingredients: a non-pre-emptive goal programming approach". Maejo International Journal of Science and Technology. 2010; 4(2): 347-359. 
[5] Jindal S, Chhibber R, Mehta NP, Kumar P. “Design and development of fluxes for submerged arc welding of HSLA steel”. International Journal of Surface Engineering \& Materials Technology. 2013; 3(1): 52-58.

[6] Jindal S, Chhibber R, Mehta NP. "Modeling flux chemistry for submerged arc weldments of high-strength lowalloy steel”. Proc IMechE Part B: J Engineering Manufacture. 2014; 1-14.

[7] Jindal S, Chhibber R, Mehta NP. "Prediction of element transfer due to flux and optimization of chemical composition and mechanical properties in high-strength low-alloy steel weld". Proc IMechE Part B: J. Engineering Manufacture. 2014.

[8] Rehal A. Development of Cost-Effective Submerged Arc Welding Fluxes for Mild Steel. SSRG International Journal of Mechanical Engineering. 2015; 64-70.

[9] Singh SS, Singh BJ. "An optimistic approach to blend recycled-slag with flux: a step towards green SAW". Int. J. Process Management and Benchmarking. 2016; 6(3): 300-327.

[10] Bhandari D, Chhibber R, Arora N, Mehta R. "Investigation of $\mathrm{TiO}_{2}-\mathrm{SiO}_{2}-\mathrm{CaO}-\mathrm{CaF}_{2}$ based electrode coatings on weld metal chemistry and mechanical behaviour of bimetallic welds. Journal of Manufacturing Processes. 2016; 23: 61-74.

[11] Khan WN, Kumar J, Chhibber R. "High-temperature wettability study of mineral waste added $\mathrm{CaO}_{-}-\mathrm{CaF}_{2}-\mathrm{SiO}_{2}$ and $\mathrm{CaO}-\mathrm{TiO}_{2}-\mathrm{SiO}_{2}$-based electrode coating for offshore welds. Proceedings of the Institution of Mechanical Engineers, Part L: Journal of Materials: Design and Applications. 2020.

[12] Singh B. "The correlation of weld microstructure and properties with element transfer in saw welds". Journal of Production Engineering. 2017; 20(1).

[13] Sharma $\mathrm{L}$, Chhibber R. "Design of $\mathrm{TiO}_{2}-\mathrm{SiO}_{2}-\mathrm{MgO}$ and $\mathrm{SiO}_{2}-\mathrm{MgO}-\mathrm{Al}_{2} \mathrm{O}_{3}$ based submerged arc fluxes for multipass bead on plate pipeline steel welds". Journal of Pressure Vessel Technology. 2019.

[14] Mahajan S, Chhibber R. "Investigation on slags of $\mathrm{CaO}-\mathrm{CaF}_{2}-\mathrm{SiO}_{2}-\mathrm{Al}_{2} \mathrm{O}_{3}$ based electrode coatings developed for power plant welds". Ceramics International. 2020.

[15] Eckenrode RT. “Weighting Multiple Criteria”. Management Science. 1965; 12(3): 180-192.

[16] Narasimhan R, Vickery SK. "An Experimental Evaluation of Articulation of Preferences in Multiple Criterion Decision Making (MCDM) Methods”. Decision Sciences. 1988; 19: 880-888.

[17] Bassioni HA. "Evaluation and analysis of criteria and sub-criteria of a construction excellence model". Engineering, Construction and Architectural Management. 2008; 15(1): 21-41.

[18] Rachmawati L. "Incorporating the Notion of Relative Importance of Objectives in Evolutionary Multiobjective Optimization”. IEEE Transactions on Evolutionary Computation. 2010; 14(4): 530-546.

[19] Serna J, Martinez END, Rincona PCN, Camargo M, Galvez D, Orjuela A. "Multi-criteria Decision Analysis for the Selection of Sustainable Chemical ' Process Routes During Early Design Stages". Chemical Engineering Research and Design. 2016.

[20] Adeyeye AD, Allu AJ. "A compromise programming approach to welding flux performance optimization". Proceedings of the International Conference on Industrial Engineering and Operations Management, Bogota, Colombia, October 25-26. 2017; 53-63.

[21] Kumar A, Maheshwari S, Sharma SK. "Fuzzy Logic Optimization of Weld Properties for SAW Using Silica Based Agglomerated Flux”. Procedia Computer Science. 2015; 57: 1140-1148.

[22] Kumar A, Maheshwari S. "Optimization of Submerged Arc Welding Rutile Based Flux constituents by Hybrid Grey, Fuzzy and Taguchi Analysis”. Advanced Materials Manufacturing \& Characterization. 2015; 5(2): 63-70.

[23] Choudhary S, Shandley R, Kumar A. "Optimization of agglomerated fluxes in submerged arc welding”. Materials Today: Proceedings. 2018; 5: 5049-5057.

[24] Sharma L, Chhibber R."Design and Development of Submerged Arc Welding Slags Using $\mathrm{CaO}_{-} \mathrm{SiO}_{2}-\mathrm{CaF}_{2}$ and CaO$\mathrm{SiO}_{2}-\mathrm{Al}_{2} \mathrm{O}_{3}$ System". Silicon. 2019.

[25] Mahajan S, Kumar J, Chhibber R. "High-Temperature Wettability Investigations on Laboratory-Developed CaO$\mathrm{CaF}_{2}-\mathrm{SiO}_{2}-\mathrm{Al}_{2} \mathrm{O}_{3}$ Flux System-Based Welding Electrode Coatings for Power Plant Applications”. Silicon. 2020.

[26] Mahajan S, Chhibber R. "Design and development of shielded metal arc welding (SMAW) electrode coatings using a $\mathrm{CaO}-\mathrm{CaF}_{2}-\mathrm{SiO}_{2}$ and $\mathrm{CaO}-\mathrm{SiO}_{2}-\mathrm{Al}_{2} \mathrm{O}_{3}$ flux system". JOM. 2019; 71(7): 2435-2444. 
[27] Mahajan S, Chhibber R. "Investigation on slags of $\mathrm{CaO}-\mathrm{CaF}_{2}-\mathrm{SiO}_{2}-\mathrm{Al}_{2} \mathrm{O}_{3}$ based electrode coatings developed for power plant welds". Ceramics International. 2020.

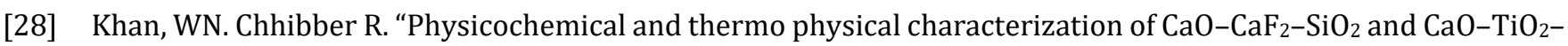
$\mathrm{SiO}_{2}$ based electrode coating for offshore welds." Ceramics International. 2020.

[29] Saaty TL. A scaling method for priorities in hierarchical structures. Journal of Mathematical Psychology. 1977; 15(3): 234-281

[30] Saaty TL. The Analytic Hierarchy Process. McGraw-Hill, New. 1980.

[31] Thipparat T, Thongpoon T. “An Integrated VIKOR and Fuzzy AHP Method for Assessing a Sustainable Research Project. World Applied Sciences Journal. 2013; 22(12): 1729-1738. 